\title{
An Institutional Marketplace
}

Family members tend to be powerful lay voices in the process of institutionalisation. Historians of psychiatry have long recognised the centrality of families in dialogues with medical and legal authorities during certification and discharge. ${ }^{1}$ In nineteenth-century Ireland, it was usually they who covered the cost of asylum care for paying patients, though less often patients with a pension, legacy or some other means paid their own fees. By the 1870s, those with means could select between public, voluntary or private care depending on how much they could-or were willing to-spend. This had implications for asylum managing bodies who were under pressure to secure fees. As we have seen, during the 1890s, the inspectors censured district asylum boards for repeatedly failing to identify patients with means. Even when they did, the inspectors complained that boards were overly lenient in the amounts requested because they tended to sympathise with ratepayers. Despite this criticism, there is evidence that boards went to great lengths to obtain fees from those they believed could afford them. Nonetheless, the revenue they collected tended to be small. ${ }^{2}$ This chapter explores the networks through which boards gathered financial information about patients and their families, their motivations for chasing fees and the inherent difficulties surrounding their negotiation and payment. As will be seen, relatives were crucial mediators in this process.

Relatives in negotiations with voluntary and private asylums enjoyed comparatively greater influence as both asylum models depended heavily

(C) The Author(s) 2018 
on patient fees. While the managing committees of voluntary asylums struggled to balance providing charity for the 'respectable' against attracting a wealthier clientele, private asylum proprietors made their livelihood from profits. Although voluntary asylums were not kept for profit, this chapter contends that by the later nineteenth century, many were forced to compete with private asylums. By the 1890s, this professional competition, together with the depressed economy, had come to inform their strategies for advertising and securing fees. ${ }^{3}$ Contrary to public criticisms of the private asylum system, examination of the outcome for patients admitted to the asylums studied reveals that private asylum patients were more likely to be discharged cured than those admitted to district asylums. Evidence of high levels of patient transfers between the three asylum sectors further underscores that the existence of a 'mixed economy of care', particularly after 1870, gave rise to an institutional marketplace for the insane. ${ }^{4}$

\section{'A Gross Abuse on the Tax Paying Public'5}

Calculating maintenance fees was a convoluted process. Investigations into families' financial circumstances were thorough, even intrusive, and could draw on a range of sources within the local community, including the asylum board and resident medical superintendent (RMS), neighbours, friends, landlords and agents, the lunacy inspectors, solicitors, pensions offices, banks and parish priests. The intricacy of the whole process defies reasoning. In some instances, families were left with little choice but to call on their bank manager, who they insisted could attest to their inability to contribute towards asylum fees. ${ }^{6}$ District medical officers were also known to intervene on behalf of relatives, signifying their rising position of authority within local communities. ${ }^{7}$

At local level, the admission of paying patients into district asylums placed new administrative burdens on asylum authorities. Although the 1870 Privy Council rules had specified rates for paying patients, they fell short of detailing how patients, families and asylum boards should agree these amounts. Since fees were based on the cost of maintaining a pauper patient (between one-quarter and the total average cost), they varied from district to district. For example, in 1890, the average cost of a pauper patient (not including casual receipts) was $£ 204 s 4 d$ at Ennis, $£ 2112 s 2 d$ at Belfast, $£ 243 s 10 d$ at Enniscorthy and $£ 25$ $16 s 10 d$ at Richmond. ${ }^{8}$ The average also changed from one year to the 
next. A crude estimate suggests that the average for the period 1868 to 1900 was $£ 24$ per annum, meaning that paying patients could legally be charged between $£ 6$ (one-quarter) and $£ 24$ (total) annually. This wide variation demonstrates the room for negotiation between the friends and relatives of paying patients and the asylum. It also indicates that paying patients were drawn from assorted socio-economic backgrounds.

Due to inconsistencies in the recording process, it was possible to calculate fees for just under two-thirds of paying patients in the four selected district asylums. Once agreed, fees were often cited in the minute books as per quarter or half year and even per day. The calculation of fees per annum in these cases therefore provides only a rudimentary estimate of actual spending power. Table 3.1 divides the recorded amounts contributed into three broad categories: $£ 12$ or less, $£ 12$ to $£ 20$, and over $£ 20$. Because many patients' fees altered with each readmission, likely reflecting a shift in economic circumstances, readmissions are included.

Most paying patients at Ennis were maintained at $£ 12$ or less, suggesting that relatives in this district had fewer means available. Patients in the urban asylums Belfast and Richmond were more likely to pay higher sums, while those at Enniscorthy were almost evenly represented across the three scales. At Belfast, fees were capped at $£ 20$, suggesting that managers there adhered more strictly to the Privy Council rules than the other asylums in the sample. This was characteristically cautious of Belfast, the only asylum studied that did not admit paying patients until officially authorised to do so.

Table 3.1 Breakdown of amounts contributed to maintenance of patients at Belfast, Ennis, Enniscorthy and Richmond district asylums, 1868-1900

\begin{tabular}{|c|c|c|c|c|c|c|c|c|c|c|}
\hline $\begin{array}{l}\text { Fees per } \\
\text { annum }\end{array}$ & Belfast & $(\%)$ & Ennis & $(\%)$ & Enniscorthy & $(\%)$ & Richmond & $(\%)$ & Total & $(\%)$ \\
\hline $\begin{array}{l}£ 12 \text { or } \\
\text { less }\end{array}$ & 14 & 33.3 & 114 & 64.8 & 22 & 36.7 & 29 & 13.9 & 179 & 36.8 \\
\hline $\begin{array}{l}£ 12- \\
£ 20\end{array}$ & 28 & 66.7 & 31 & 17.6 & 19 & 31.7 & 79 & 38.0 & 157 & 32.3 \\
\hline $\begin{array}{l}\text { Over } \\
£ 20\end{array}$ & $\mathrm{~N} / \mathrm{A}$ & $\mathrm{N} / \mathrm{A}$ & 31 & 17.6 & 19 & 31.7 & 100 & 48.1 & 150 & 30.9 \\
\hline
\end{tabular}

Compiled from Belfast, Ennis, Enniscorthy and Richmond Minute Books and Enniscorthy and Richmond superintendent's notices 
The extent to which other asylums were willing to exceed the Privy Council limit varied greatly. If the average cost per head during the period was $£ 24$, Ennis, Enniscorthy and Richmond were clearly in breach. Richmond was particularly culpable: $41 \%$ of known maintenance fees were $£ 25$ or more, while three patients contributed $£ 40, £ 51$ and $£ 57$. The tendency to charge over the average was less at Enniscorthy $(8 \%)$ and Ennis (7\%), where the maximum sums received were $£ 25$ and $£ 30$ respectively. ${ }^{9}$ Nevertheless, except for Belfast, the fees charged in some instances were on a par with the voluntary asylums. Richmond's ability to secure higher fees is curious given its proximity to all four of the voluntary asylums, which were generally seen as preferable sites of care.

The notification process for families was equally haphazard. While some families were told they must pay fees during the committal process, others were contacted long after patients were admitted with a view to securing payment. On the contrary, those initially admitted as paying patients could become 'paupers' following a change in economic circumstances. The first point of contact, in all cases, was usually the RMS, who was responsible for outlining the procedure. For example, in 1883, the Enniscorthy asylum's RMS, Thomas Drapes, wrote to John W., a patient's husband:

it would be well if you would come up here on Thursday next when the Board meets: as your circumstances being above those of 'pauper', the Governor will expect you to pay something for your wife's maintenance while in the asylum. The average cost is $£ 22$ per annum and if you let me know in writing that you are prepared to pay at that rate you need not come up: but if otherwise it is advisable that you should attend at the Board and state what your circumstances will admit of you paying. ${ }^{10}$

This letter suggests that fees at Enniscorthy were initially fixed at the highest rate. Thereafter, relatives could attempt to agree a smaller sum. Although this practice was not required by the Privy Council rules, it was probably adopted to apply pressure on families to cover costs.

At Ennis, the board took a different approach. There, relatives were subjected to a thorough investigation of their circumstances, following which an appropriate fee was agreed. ${ }^{11}$ Surviving correspondence books for the Ennis asylum contain letters written by families, friends and acquaintances, providing first-hand accounts of the negotiation process. The sheer volume of correspondence relating to maintenance 
contributions in the Ennis asylum-approximately 270 letters identified for the period 1868-1900-indicates the disproportionate amount of administration generated by the reception of paying patients in district asylums. ${ }^{12}$ It is unclear how this practice was handled at Belfast or Richmond. In all cases, it fell upon the boards of governors to assess individuals' means and arrive at a suitable maintenance fee. Acting in a secretarial capacity for the board, the RMS continued to correspond with families until matters were resolved.

Aside from payment from relatives, the boards could apply to other sources of income. ${ }^{13}$ At Ennis, knowledge that a patient was the beneficiary of a will could spark investigations and, in some cases, the asylum's solicitor furnished the board with copies of wills and other legal documents. ${ }^{14}$ Some patients used their pensions to pay for their maintenance, although under the 1875 Act, this was not required when patients had dependents. ${ }^{15}$ Asylum boards apparently adhered to this law. In the case of Joseph H., a retired telegraph clerk at Richmond, the secretary to the General Post Office informed the asylum board that 'as he has no nearer relative than a brother living ... the pension due to him should be paid to the asylum'. ${ }^{16}$ However, when Anne R., wrote to Richmond, explaining that she was 'very poor' and had 'three small children', the board resolved not to claim her husband's pension. ${ }^{17}$ Likewise, at Enniscorthy, Drapes redirected the pension of Patrick K., to his brother Thomas, 'he being in needy circumstances and having supported [the patient] for 3 years past' at home. These passing references bring home the reality for many families struggling to support a mentally ill relative. The board's compassion on this occasion was limited, however, as once Thomas died, they swiftly applied the pension to Patrick's maintenance. ${ }^{18}$

In some cases, asylum boards reached agreement with a patient's previous employer or pensions office to divide pensions between the asylum and the family. In 1879, the Richmond board wrote to the chief commissioner of the Dublin Metropolitan Police concerning a patient, John M., who had a 'wife and three young daughters who have no other means of living'. The board agreed to allocate $£ 27$ out of John's annual pension to his family and the remaining $£ 13$ to his maintenance. ${ }^{19}$ The Ennis board initially demonstrated similar lenience in the case of pensioners. ${ }^{20}$ Having learned that a patient's father was 'a very poor man' for whom the patient had been 'the chief means of ... support' prior to his illness, the board resolved to reduce his maintenance to $£ 10$ and to refund $£ 108 s$ per year of the patient's excise office pension to the man's 
father. ${ }^{21}$ However, in 1890, when a different patient's father requested that the Ennis board allow him to keep part of his son's pension from the Inland Revenue Board, the board refused because allowances from pensions had been 'disallowed by the Auditor in a similar case'. ${ }^{22}$

Families often used the workhouse as leverage when trying to evade fees, expressing fears of ending up there if forced to pay. One patient's father pleaded with the Ennis board to let him keep part of his son's pension 'to enable me to support myself, wife and family otherwise we must become inmates of the workhouse and lie a burthen on the ratepayers' ${ }^{23}$ Whether this fear was genuine, or merely served to remind the board that relatives too might become a burden on the ratepayer, is hard to decipher. However, as we shall see, several relatives, particularly in the Ennis district, presented themselves as being on the borderline of pauperism. Given the harsh economic conditions for many families, particularly farmers, in this district, it is likely that at least some of these claims were justified.

At their most extreme, the Ennis board threatened to discharge patients to the workhouse, a tactic that usually provoked even the most reluctant relative to contribute fees. ${ }^{24}$ The Privy Council rules did not offer any specific protection to paying patients in this position. Moreover, while the 1875 Act empowered RMSs to acquire maintenance fees by various means, it did not sanction the discharge of patients whose fees were not paid. ${ }^{25}$ The Act did, however, encourage the transfer of 'harmless' asylum patients to workhouses and in these cases the lunacy authorities continued to pay maintenance costs. ${ }^{26}$ This was not a straightforward procedure. Workhouse guardians used destitution as admission criteria, posing problems for the transfer of paying patients to the workhouse. ${ }^{27}$

In 1892, the clerk of Tulla Union workhouse, County Clare, wrote to Richard Phillips Gelston, the RMS at Ennis, informing him that the board of guardians had heavily criticised the asylum for transferring an ex-policeman, who had been a paying patient, terming it a 'violation of the law'. Notably, this criticism was not based on the transfer of a nonpauper to the workhouse. Instead, the board of guardians was concerned that the patient, who had been committed to the asylum as a dangerous lunatic, posed a threat to the inmates of the workhouse. ${ }^{28}$ One explanation for the Tulla guardians' lack of concern is the 1875 Act's stipulation that any expenses in respect of lunatics transferred to the workhouse 
must be paid by the governors out of the applicable funds. ${ }^{29}$ In consequence, any paying patient transferred to the workhouse was supposed to be maintained out of the asylum's finance base rather than the poor rates, although Poor Law guardians encountered difficulties when they sought payments from the asylum's authorities. ${ }^{30}$

The frequency in transferring patients to the workhouse for non-payment should not be overestimated. In most cases when it was threatened, it was not carried out. This was because, following admission, patients in district asylums had a legal entitlement to relief, determined by their mental condition rather than their ability to contribute towards maintenance. ${ }^{31}$ For instance, when the Ennis board threatened to transfer William $M$ to the workhouse, his brother-in-law wrote to the asylum on behalf of the patient's father, Michael, who he claimed was 'just as much impaired in his mind as his son'. Michael had allegedly become 'very much disturbed in his mind on account of his son being [potentially] sent to the workhouse'. As a result, his son-in-law informed the Reverend McNearmond that they had 'a small sum of money ... thought he might be able to afford to contribute a little yearly towards his son's maintenance'. Having later discovered that the father was unable to contribute, the board resolved to retain William as a pauper patient in the asylum. ${ }^{32}$

In rural districts like Ennis, key considerations in the assessment of families' financial circumstances were land acreage, stock, number of dependents and reputation within the community. The case of Mrs. G., whose daughter was admitted to Ennis, is typical:

Mrs G can well afford to pay at least $[£] 6$ annually for the support of her daughter. She holds a good well stocked farm only one boy and girl at home. Some 3 or 4 years ago she paid as much as $£ 500$ for a fine farm and some stock for one of her sons at Mount Rivers. She is reputed by her neighbours to have plenty of money on deposit therefore she ought to pay the small sum named. ${ }^{33}$

This emphasis on the visible trappings of wealth stemmed from the nature of the board's investigations, which relied on local knowledge from members of the community. Most of the evidence gathered by boards was based on second-hand information, though relatives sometimes disputed these channels when asked to contribute. H. Skerrett, the land agent for one patient's brother, informed the RMS that he believed 
'some enemies of his [the patient's brother's] have been at work trying to make you believe that he is rich'. Skerrett insisted 'this is not true. I know the position of the $\mathrm{D}[-]$ s well and I assure you they have nothing to spare'. ${ }^{34}$ Ominously, the mother of another paying patient wrote to Ennis asylum warning that 'there are malicious scribes in this locality giving false names \&c of whose communications you should take no notice ... My opinion is those scribes are only humbugging the governors'. As evidence, she provided the following example:

It appears that some 'Thomas K., Kilmilhil' wrote to you lately. Well there is no such householder in this parish and a little boy of that name got your letter saying he knew nothing about the matter and gave the letter to me. ${ }^{35}$

In most cases, however, informants were contacted directly by the RMS, possibly to guard against the danger of 'malicious' individuals providing false accounts.

Signifying their social influence in rural communities, landlords and land agents played an important role in supplying financial evidence. For example, a letter from a land agent, R.D. O'Brien, to Gelston stated that a patient's husband, Henry P., paid him an annual 'average fair rent' of $£ 31$ 15s. O’Brien urged Gelston to take into consideration that:

the loss of a wife's help is in itself a heavy blow to a dairy farmer and as $\mathrm{Mr} \mathrm{P}$ has to meet his calls and rear a young family out of the small farm he holds, I do not see how he can manage to keep his wife in the asylum. He will explain his case to you himself and I hope you will consider it passionately. ${ }^{36}$

Several asylum board members were also landlords and their knowledge of the locality placed them in a privileged position to comment on families' financial affairs.

It is plausible that landlords and other respected members of the community disseminated advice to relatives on how best to negotiate with the asylum. Certainly, as Cox has found in her study of dangerous lunatic certifications, magistrates, clergy, and hospital and workhouse staff all advised families who wished to commit a relative to the Carlow asylum. ${ }^{37}$ Given the small size of many rural communities, some families would have known board members personally. Henry P.R., who had both a brother and a sister in the Ennis asylum, wrote repeatedly to 
the board, attempting to explain his delay in contributing towards their maintenance. A solicitor and a landlord, Henry was apparently struggling financially due to the reduction in his tenants' rents following the introduction of the 1881 Land Act. ${ }^{38}$ Five years later, the matter had not been resolved and Henry appealed to the board for sympathy:

I think the governors and the auditors ought to know very well how hard it is to collect rents from Tenants ... I am much surprised that they would take the course in the matter they are all Landlords themselves and I think they might act as landlords are acting to one another now a days and not insist on the payment of the arrears particularly when I cannot get it myself from the tenants. ${ }^{39}$

Henry's difficulty in paying for his relatives' maintenance fees was by no means uncommon. Asylum boards often struggled to decide who should be compelled to pay. In 1871, the Belfast board resolved to form a Committee 'to inquire into the whole subject of pay patients, including those in the House'. The committee was intended to provide counsel on how best to distinguish between those 'able to pay' and 'entirely destitute'. ${ }^{40}$ Two months later, the matter was found to be more complicated than anticipated. The committee reported that of the eight patients identified as being able to contribute:

five had stated their entire inability to give any assistance ... the husband of Jane $\mathrm{H}$ was about removing her home immediately and that the mother of Ellen $\mathrm{T}$ hoped soon to be able to pay for her at the rate of $£ 15$ per annum and that William A's friends would pay the average ... of the general cost for him in the event of his continuing here but which would not likely be the case as other arrangements were endeavouring to be made in regard to him. ${ }^{41}$

Following their initial enthusiasm in setting up the special committee, the Belfast board apparently lost interest and no further action was recorded.

Even when relatives agreed to contribute, payment was not always forthcoming. In these cases, the RMS assumed the role of debt collector on the board's behalf. ${ }^{42}$ Eventually letters took the form of demand notices, threatening to discharge patients if their fees were not paid. In 1881, Enniscorthy's RMS, Joseph Edmundson, went so far as to threaten the father of patient Mary F., if he failed to pay for her 
maintenance: 'in case you do not agree to these terms,' he warned, 'you will have to remove her home at once. 43 Similarly, the Richmond board threatened to discharge Eliza $\mathrm{H}$., if her brother failed to continue paying for her in full. ${ }^{44}$ This was not strictly feasible. As we have seen, once admitted, district asylum patients were legally entitled to relief until they were deemed 'recovered'. ${ }^{45}$ Given that this practice was illegal, it is likely the asylum authorities were simply wielding discharge as a means of intimidation rather than something they intended carrying out. Due to the greater number of paying patients at Richmond, the board for that asylum often resorted to their solicitor to recover fees. ${ }^{46}$ The Ennis board also employed their solicitor and were particularly ruthless in their pursuit of maintenance fees. ${ }^{47}$

The question of whether asylum boards could charge dangerous lunatics for their maintenance created yet more confusion. Several district asylums admitted non-paupers under the 1838 and 1867 dangerous lunatic acts, which did not require proof of poverty. ${ }^{48}$ While Finnane has suggested there was little asylum boards could do to enforce payment of fees in these cases, ${ }^{49}$ at local level they proved exceptionally vigilant when inquiring if dangerous lunatics were possessed of means. From the 1870s, numerous patients admitted to Belfast, Ennis and Enniscorthy as dangerous lunatics were quickly redesignated as paying patients. ${ }^{50}$ Nonetheless, as late as 1891, Enniscorthy's board of governors wrote to the lunacy inspectors inquiring whether dangerous lunatics could be charged maintenance. ${ }^{51}$ Although no reply is documented in the Enniscorthy records, in the same year, the inspectors wrote to Ennis' RMS, Gelston, about the same issue. The inspectors stated that those committed as dangerous lunatics could not be named paying patients 'until they are duly certified to be no longer dangerous .... and removed from the class of dangerous lunatics in the asylum'. ${ }^{52}$ Subsequently, there is no record of dangerous lunatics being automatically renamed as paying patients in any of the four case studies.

Despite the rigorous pursuit of maintenance fees, boards of governors were sensitive to a change in relatives' financial circumstances and renegotiated fees in line with new developments. This worked in both directions and fees were raised and lowered. In 1877, Enniscorthy's RMS, Joseph Edmundson, wrote to Miss K., with a view to raising her father's maintenance as the board 'consider it much too small'. ${ }^{53}$ In 1890, the asylum's solicitor, John A. Sinnott was instructed to apply to the next Quarter Sessions in Gorey, County Wexford, for an increase in a patient's 
maintenance fee, 'there being reason to believe that the lunatic's property is able to contribute that amount'. ${ }^{54}$ Patients at Richmond were granted a reduction in maintenance fees if their case was approved. ${ }^{55}$ In 1878, having inquired into the financial affairs of Philip B's family, his maintenance was reduced from $£ 16$ to $£ 12$ per annum. The following year, the board found Philip's father unable to pay and at this point the patient was renamed a 'pauper' patient. ${ }^{56}$ Likewise, in 1897, in the case of Edward C., the Enniscorthy board, 'taking into consideration [his] large family', did not request payment. ${ }^{57}$ At Belfast, patients could also be changed from paying to pauper status when evidence was provided that the family had suffered a 'reversal in fortune'. ${ }^{5}$ These examples illustrate that in cases where the relatives of patients were genuinely unable to contribute towards maintenance, district asylums retained their primary function as 'asylums for the lunatic poor'.

While it is conceivable that patients' relatives exaggerated their financial despair to avoid paying fees, some went to great lengths to contribute, hoping that the patient would recover before their limited means were exhausted. In 1892, the mother of Ennis paying patient Mary F., wrote to Gelston:

In the full hope and expectation that my poor daughter would recover under your skill and management, I strove by every means in my power to pay $[£] 20$ a year and actually borrowed the money at high interest and deprived myself and family of the necessaries of life to enable me to do so. Now, however, I deeply regret to say that owing to my present embarrassments it is utterly out of my power to pay any greater sum than $£ 10$ yearly. ${ }^{59}$

Patients who remained in the asylum longer than expected were a considerable source of financial strain for their relatives. In 1899, James K. wrote to the Ennis board of governors concerning his sister Margaret's maintenance:

As the doctor of my district told me she would be well after a few months but as there is no improvement I cannot continue to contribute as I live on the side of a poor wet mountain and I have plenty to do to pay rent and many other calls besides this. This girl has a room in my house. And beyond this I am not bound to maintain her, so I hope gentlemen you will be considerate for a poor man. And anytime she is fit to be discharged I will receive her back. ${ }^{60}$ 
The parish priest also wrote on James' behalf:

he tells me he only consented to pay towards the maintenance of his sister referred to on the representation of the medical attendant who said his sister's ailment was only a nervous attack from which she would be well in a few months. ${ }^{61}$

Margaret remained in the asylum free of charge and was discharged 'relieved' five months later. ${ }^{62}$ Another patient's husband wrote that 'the last instalment which I paid I had to raise it in the bank where I am still paying interest for it. Besides I am greatly involved in debt. I have 10 in family and three of them in a delicate state of health'. ${ }^{63}$ In this case, the board resolved that the payment was 'to be confirmed'. ${ }^{64}$

Several of the letters the Ennis asylum received from families chronicled the deterioration of their financial circumstances and the hardship and struggles endured by many in the Ennis district. In 1889, one paying patient's brother explained how their father had 'lost about $£ 1200$ by the failure of the Munster Bank, the cottages specified have fallen much below the former estimated value between reduction in rent and other losses in the line of non-payment and constant requirements for repairs \&c'. ${ }^{65}$ The following year, the father of patient Patrick McM complained of being 'destitute. I lost 9 head of cattle, a horse, 6 breeding ewes and a ram in the years $86, ' 7$ and ' $8 \ldots$ I owe a lot of rent which I cannot pay'. ${ }^{66}$ In addition to outlining their financial problems, relatives sometimes appealed to asylum boards for compassion on the grounds of their own poor health. One father described himself as 'old and feeble' and subsequently had his son's maintenance reduced, while another described his 'own direful affection on a crutch with only one leg' ${ }^{67}$

Friends and relatives also invoked the boards' sympathy on patients' behalf. In 1889, D. Flannery, a parish priest, wrote of a patient:

he is deeply in debt and has little or no stock on a wretched farm. $\mathrm{He}$ belongs to a class of man who are poorer than the beggars and more to be pitied - struggling farmers. Of course, now that there is no one able to look after the place properly things will become worse. ${ }^{68}$

Although chiefly concerned with outlining their poverty, friends frequently underscored families' 'respectability', reflecting contemporary 
anxieties about the undeserving poor gaining charity or state aid. ${ }^{69}$ In 1899, parish priest, James Cahir wrote of John K's family:

The children have behaved themselves most sensibly and through their hard work and good sense are improving their condition but they are not yet able to stock their land and they owe a years' rent. Under these circumstances if the Governors press $\mathrm{K}[\ldots]$ on the maintenance of his mother the consequences will be that the family will be broken up and eventually they will have to abandon the farm and seek some other mode of livelihood.

On this occasion, the payment was 'remitted for the present'. ${ }^{70}$ Writing of another family, seven years earlier, the same priest described a patient's father as a 'quite honest, industrious but yet struggling poor man ... general honesty of character and truthfulness give entire credit to his statement'.71

Notwithstanding the painstaking pursuit of fees, the proportion of money generated was negligible. ${ }^{72}$ Table 3.2 provides a detailed breakdown of the four selected asylums and indicates that from 1875 to 1895 the proportion of revenue from admission fees was between

Table 3.2 Proportion of contributions towards patients' maintenance at Belfast, Ennis, Enniscorthy and Richmond district asylums, 1875-1895

\begin{tabular}{lccc}
\hline Asylum & \% District & \% Treasury Grant & \% Paying Patients \\
\hline 1875 & & & \\
Belfast & 71.7 & 27.4 & 0.9 \\
Ennis & 69.2 & 28.9 & 1.9 \\
Enniscorthy & 68.9 & 29.6 & 1.5 \\
Richmond & 71.4 & 27.3 & 1.3 \\
1885 & & & \\
Belfast & 60.1 & 37.8 & 2.0 \\
Ennis & 51.5 & 43.3 & 5.1 \\
Enniscorthy & 51.9 & 46.4 & 1.6 \\
Richmond & 50.3 & 46.8 & 2.8 \\
l895 & & & \\
Belfast & 58.4 & 38.8 & 2.7 \\
Ennis & 54.1 & 41.8 & 4.1 \\
Enniscorthy & 55.8 & 41.3 & 2.9 \\
Richmond & 65.2 & 32.8 & 2.0 \\
\hline
\end{tabular}

Compiled from Reports on District, Local and Private Lunatic Asylums in Ireland, 1877, 1887, 1897 
approximately $\mathrm{l}$ and 5\%. Ennis' figures are higher than those of the other asylums, suggesting that this board managed to extract more fees, despite the poverty in that district. Nonetheless, while these figures are slightly higher than the national average of about $1 \%$, they clearly demonstrate that the admission of paying patients did little to alleviate the financial burden placed on the ratepayers and the treasury by the district asylum system.

Given the lack of legislative guidance, the frequent expressions of borderline poverty from relatives and the limited revenue generated, it is difficult to ascertain the boards' motivation in chasing maintenance fees. A letter from a W.S. Studdert, possibly a governor's relative, ${ }^{73}$ to Gelston in 1888 offers one explanation:

I consider it a gross abuse on the tax paying public to subscribe anything towards James W's daughter even though the government do contribute $£ 10.8 .3$ towards her support he could afford to pay for her in Dublin why not in Clare? Her parents are considered to be in most affluent circumstances, he could in my opinion better or as well afford to pay for her as perhaps some of this Board for this child. Yesterday he buried his son, he had the best hearse and mourning coach out from Limerick, he had a draper from Killaloe pairing out linen and crape hat bands. ${ }^{74}$

This excerpt illustrates contemporary concerns that those who could afford to contribute might instead become a burden on the rates. It also goes some way towards explaining the exertions of asylum boards to collect fees. Studdert concluded that 'under these circumstances I decline paying for James W's daughter ... I shall not pay if I can, so will not let the matter rest here'. ${ }^{75}$ The $£ 108 s 3 d$ referred to was the annual sum received per patient in Ennis from the 'four shillings' Treasury grant, which, as Chap. 2 discussed, subsidised the maintenance of part-paying patients out of the Treasury. ${ }^{76}$ If Studdert's sentiments were representative of the board's motivations, then they too were concerned with the protection of the ratepayer. Certainly, Cox has argued that governors were 'generally anxious to reduce the local taxation burden' created by district asylums. ${ }^{77}$ This echoes the lunacy inspectors' criticism of asylum boards in 1895 , for not putting pressure on relatives to contribute more than a certain amount in order to avail of the four shillings rule. ${ }^{78}$

Some relatives were aware of the Treasury grant and even appealed to the asylum board to reduce their fees to become eligible for 
subsidisation. In 1883, Mary C., wrote to Ennis' RMS, Daxon, asking for her son's maintenance to be reduced from $£ 24$ to $£ 10$ per annum 'at which rate I understand you will be entitled to receive a yearly contribution from the Government nearly equal to the reduction' ${ }^{79}$ Likewise, in 1889 , James K., requested a reduction of $£ 2$ for his sister's maintenance 'to obtain the Government in aid for her maintenance as indeed I could not afford to pay more than $£ 10$ for her maintenance' ${ }^{80}$ The fact that boards did, on a number of occasions, reduce maintenance fees lends credence to the lunacy inspectors' criticism and suggests that boards were, in fact, 'best consulting the interests of the rate-payer'. 81

\section{'Not Kept for Profit'82}

During the nineteenth century, the managing committees of voluntary asylums became progressively intent on promoting their establishments and attracting patient fees. This section examines how the two case studies, Bloomfield and Stewarts, ensured their survival within the institutional marketplace. As we have seen, Bloomfield's managing committee became increasingly willing to admit non-Quaker patients but charged these patients much higher rates than their Quaker counterparts. The admission of these wealthy patients not only supplied surplus funds but also made Bloomfield respectable and socially inviting. This was important to Bloomfield's ethos of providing aid for Quakers who had 'fallen on hard times'. Stewarts embodied a more complex form of voluntary care. While the government continued to cover the costs of Stewarts' dwindling 'government patient' population, an increasing number of paying patients came to occupy the lunatic branch. Excluding the government patients, these patient fees were the sole financial base for the lunatic branch, while the managing committee repeatedly identified them as the most significant source of funding for the imbecile branch. ${ }^{83}$

As Chap. 2 discussed, voluntary asylums charged higher rates of maintenance than district asylums. From 1858 to 1900, more than half of the documented Stewarts' patient fees were between $£ 41$ and $£ 60$. At Bloomfield, almost half of recorded fees were over $£ 100$ (see Table 3.3). While Bloomfield's fees were mostly on a par with the private asylums, some patients were kept at lower rates. Like St Patrick's, Bloomfield provided relief for the 'respectable poor' as well as the wealthy. Although by the second half of the nineteenth century St Patrick's lowered its fees, restating its original intention of providing for the poor, ${ }^{84}$ Bloomfield 
Table 3.3 Documented maintenance fees, Stewarts and Bloomfield, 1858-1900

\begin{tabular}{lcccccc}
\hline Fees $($ to nearest $£)$ & Bloomfield & $(\%)$ & Stewarts & $(\%)$ & Both & $(\%)$ \\
\hline Identified as free & 7 & 1.7 & 0 & 0.0 & 7 & 0.7 \\
Under $£ 20$ & 0 & 0.0 & 2 & 0.4 & 2 & 0.2 \\
$£ 20-£ 25$ & 3 & 0.7 & 8 & 1.5 & 11 & 1.8 \\
$£ 26-£ 40$ & 16 & 3.8 & 30 & 5.7 & 46 & 4.9 \\
$£ 41-£ 60$ & 30 & 7.1 & 278 & 53.3 & 308 & 32.7 \\
$£ 61-£ 100$ & 62 & 14.8 & 33 & 6.3 & 95 & 10.1 \\
$£ 101-£ 150$ & 99 & 23.6 & 2 & 0.4 & 101 & 10.7 \\
$£ 151-£ 200$ & 97 & 23.1 & 1 & 0.2 & 98 & 10.4 \\
$£ 201-£ 240$ & 2 & 0.5 & 0 & 0.0 & 2 & 0.2 \\
Not documented & 104 & 24.8 & 168 & 32.2 & 272 & 28.9 \\
Total & 420 & 100.0 & 522 & 100.0 & 942 & 100.0 \\
\hline
\end{tabular}

Compiled from Patient Accounts (Stewarts, Stewarts Patient Records) and Bloomfield Ledgers, 18581900 (FHL, Bloomfield Records)

continued to charge high fees for the remainder of the century. This is because, unlike St Patrick's, Bloomfield was not founded from the bequest of an individual and its managing committee had the freedom to set terms as they saw fit. Bloomfield's only limitation was to provide for the small number of Quakers who could not afford private asylum care.

The much lower fees at Stewarts reflect its managing committee's ethos of caring for the 'middle classes', a preoccupation which was reflected in the institution's name: 'Asylum for Lunatic Patients of the Middle Classes'. ${ }^{85}$ In addition to a strong emphasis on providing free or affordable care for the training of imbecile children, accommodating patients at low rates was considered paramount. In 1872, at the annual meeting of the committee that had established Stewarts, Stewart stated that he had been managing the asylum for twelve years 'for the maintenance of middle-class lunatics'. Stewart professed that it was the only asylum in Ireland catering for that class and that its existence was a 'great boon to the middle-classes of this country'. ${ }^{86}$ The terms of admission included in each annual report reflected this ethos. The earliest extant annual report, published in 1871, stipulated that the asylum branch was:

intended for patients whose means will allow of their paying for the use of all appliances necessary for restoration to health and for protection, but not for the luxurious accommodation of first class private asylums. ${ }^{87}$ 
Fees at Stewarts were on a graded scale (see Table 3.4) and in 1871 were $£ 36$ per annum. Those requiring a 'special attendant' were charged extra, while additional charges were incurred when friends or relatives did not supply clothing. 'Accommodation of a superior kind' was available for a 'few female patients' at the rate of $£ 52$ per annum. ${ }^{88}$ Two years later, the upper limit of $£ 52$ was abolished. ${ }^{89}$ In 1874 , the minimum rate of maintenance was raised to $£ 40$ per annum and in 1878 , to $£ 50$ where it stayed for the remainder of the century. ${ }^{90}$ Yet, some patients were maintained at lower rates than those specified. In 1872, one patient was admitted at just $£ 12$ per annum and in 1900, two patients were charged just $£ 30$ each. $^{91}$ Overall, these rates were much higher than district asylum fees, revealing a gap between public and voluntary care. Nonetheless, those who could afford the highest rates at district asylums might also avail of the lowest fees in voluntary asylums such as Stewarts, suggesting that some families could select between the two forms of care.

Although voluntary asylums were not kept for profit, the managing committees for both Stewarts and Bloomfield were compelled to compete with private asylums for their clientele. In a bid to disassociate themselves from the district asylums, the managing committees stressed the enhanced privacy their asylums could provide. Privacy was an important consideration for the relatives of the mentally ill. In the English context, Charlotte MacKenzie has found that families desired confidentiality when committing patients to Ticehurst, a private asylum located in the South of England. ${ }^{92}$ In a similar vein, Suzuki has argued that the families of the mentally ill in England were particularly troubled by the public exposure of their relatives' disruptive behaviour, which often determined decisions to commit them to an institution..$^{93}$

Table 3.4 Maintenance fees at Stewarts

\begin{tabular}{lcl}
\hline Year & Minimum fee per annum & Alternative rates \\
\hline 1871 & $£ 36$ & Superior accommodation (females) $£ 52$ \\
1873 & $£ 36$ & No upper limit \\
1874 & $£ 40$ & No upper limit \\
1878 & $£ 50$ & No upper limit \\
1890 & $£ 50$ & $£ 5$ for one month, no upper limit \\
1897 & $£ 50$ & No upper limit \\
\hline
\end{tabular}

Compiled from The Stewart Institution and Asylum Report 1871, 1873, 1874, 1878, 1890, 1897 
This had long been the case in Ireland. As early as 1814, Bloomfield's managing committee stated that much care has been taken to keep the patients 'in a due degree of privacy'. ${ }^{94}$ The committee was concerned that 'fear of publicity' was deterring families from committing their relatives to Bloomfield. ${ }^{95}$ However, by the 1860 s, Bloomfield's visiting physician, Dr. Valentine Duke, reported that:

the public seem now to look upon the affliction of lunacy, less as a disgrace to be carefully concealed from all outside the family circle, than they have been in the habit of doing heretofore and that they are more ready to avail themselves promptly of the many resources and advantages which are afforded in a well regulated Asylum. ${ }^{96}$

Despite this alleged shift in public attitudes, in 1884 Stewarts' managing committee was still appealing to families' desire for confidentiality. The committee was keenly aware that Stewarts offered an alternative to 'respectable families' who might otherwise be forced to commit relatives to a district asylum, a far more public procedure. This latter solution, the managing committee insisted:

would be in many cases most disagreeable, as although the District Asylums are, as a rule, extremely well managed the greater degree of publicity, combined with the comparative inferiority of the dietary, would render such places objectionable to all who could resort to a more private establishment whose rates were not prohibitive. ${ }^{97}$

The managing committee routinely emphasised the shortcomings of district asylum care. In 1896, they claimed:

no greater hardship can exist for people of respectable position, but with very small means, than to be obliged to place their insane relatives in the district asylums often by passing through a disagreeable public ordeal and by the foundation of this Asylum it was intended to mitigate this inconvenience to some extent by providing accommodation suited in degree to the ailment and the means of the patient. ${ }^{98}$

This 'disagreeable public ordeal' was most likely committal as a dangerous lunatic. Cox has highlighted the very 'public nature' of dangerous lunatic certifications which were heard at the petty sessions throughout Ireland. ${ }^{99}$ Where no places existed for paying patients in district 
asylums, which was particularly likely at the over-crowded, neighbouring Richmond asylum, prospective patients and their families would almost certainly have faced dangerous lunatic certification. This contrasted with admissions to asylums in Britain whose examination and certification often took place in their own or their relative's home. ${ }^{100}$ There were some exceptions, however, such as in cases of infanticide. ${ }^{101}$ Alternatively, Stewarts' committee may have been hinting at the intrusive nature of testing paying patients' means. Either way, Stewarts' committee was appealing to the high value the wealthier classes placed on confidentiality. In 1886, the managing committee stressed that although the asylum had an 'ample extent of ground suited for exercise' and 'every reasonable liberty consistent with safety is afforded to patients ... every precaution to ensure the necessary privacy is taken'. ${ }^{102}$

The language used to describe Stewarts asylum branch was also that of the domestic or private sphere and the institution was characterised as 'a comfortable home for ladies and gentlemen of limited means'. ${ }^{103}$ The managing committee proudly boasted that a number of patients preferred to remain voluntarily at Stewarts, 'regarding it as a comfortable home'. ${ }^{104}$ In relation to the eighteenth century, Joan Busfield has also noticed a tendency for private asylum advertisements to use this language, where an underscoring of the 'residential' nature of private asylum care sought to detract from the wealthier classes' reluctance to institutionalise their relatives. ${ }^{105}$ This was also the case in nineteenth-century Ireland. Relatives faced with selecting between public and voluntary care could draw comfort from the enhanced privacy afforded by institutions like Stewarts. Meanwhile, those able to afford private care might settle for cheaper accommodation in voluntary asylums, based on the assumption that these establishments could offer 'domestic' and private accommodation which rivalled the more expensive private ones.

While providing accommodation at lower rates than private asylums, and dissociating themselves from district asylums, both the Bloomfield and Stewarts managing committees worked hard to attract patients who could pay higher rates. In the 1840 s, Bloomfield's managing committee decided to make an 'addition of several commodious apartments' to the existing building, which they expected would 'afford ample accommodation and every requisite for those who have moved in more affluent circles'. ${ }^{106}$ Although the committee had evidently widened its target market, in 1856, they complained that large numbers of patients were paying 'but low rates'. ${ }^{107}$ By this point, Bloomfield housed 
approximately twenty-five patients. A decade later, members of a general meeting of the Society of Friends encouraged the committee to lease the adjoining premises of Swanbrook in Donnybrook, which consisted of a house on about three acres of ground and was 'thoroughly remodelled and furnished and the pleasure ground of both suitably laid out'. The committee intended this house not only to allow for a 'much more perfect classification' and in turn segregation of patients by condition, but also supplied 'superior apartments' for first class patients. ${ }^{108}$

Stewarts' managing committee took similar steps. In the late 1880s, when Stewarts housed approximately 115 patients, the managing committee decided to extend the accommodation in the lunatic branch. By then, the committee had stopped framing this branch with its charitable contribution to the imbecile branch, instead placing more emphasis on its 'general usefulness to society' in caring for those unable to afford accommodation elsewhere. The committee now applied a portion of the profits from the lunatic branch to building work. Apparently anticipating a negative response from subscribers, they took pains to justify their departure from previous practice:

though the intention of the late Dr. Stewart was that any profit arising from it [the asylum branch] should be applied to assist the [Imbecile] Institution, the Committee are better satisfied in seeing the Asylum fulfil its own mission usefully to the community than become a permanent source of any large income, as they are confident that any deficiency in the funds would ultimately be made good by those interested in the support of the [Imbecile] Institution. ${ }^{109}$

By seeking patients from the wealthier grades of society, Stewarts and Bloomfield were entering into direct competition with private asylums. This was not originally envisaged. In 1885, the Stewarts' committee stated they did not 'seek to interfere with other Private Asylums', proclaiming themselves satisfied to be 'found useful to patients of limited means'. At this point, the committee insisted, they aimed to 'studiously avoid the principle of competition with other Asylums'. ${ }^{110}$ However, the committee was eager to point out that many patients were transferred to Stewarts 'from more expensive establishments and neither themselves nor their friends have found any occasion to regret the change'.111

By 1891, the number of patients in Stewarts' asylum branch had decreased. Although the committee reported that several 'very aged 
residents' had died, they recognised that asylum care had been 'largely extended elsewhere of late'. ${ }^{112}$ This was presumably a reference to expanding private asylums such as St John of God's, which was providing accommodation at competitive rates, though St John of God's accommodated primarily Catholics, while Stewarts catered mostly for members of the Church of Ireland. It was at this point that the Stewarts' managing committee decided to alter the internal accommodation and provide for those of the wealthier classes. ${ }^{113}$ By 1893, the managing committee was openly acknowledging the competitive nature of asylum provision for paying patients, noting that the element of competition by other establishments of a similar character tends to render the number of patients under treatment subject to variation'. ${ }^{114}$

The building alterations undertaken at Stewarts greatly changed its dynamic, as the asylum now offered higher standards of accommodation for those able to afford it. The apartments previously occupied by the RMS, Frederick Pim, were converted to accommodation for 'ladies and gentlemen who were desirous of greater privacy than we were enabled to give under previously existing circumstances'. Pim, meanwhile, was moved to a separate residence nearby. ${ }^{115}$ The larger sleeping apartments were rearranged to provide several smaller private apartments for individual patients. ${ }^{116}$ By 1897, Stewarts' terms of admission now stated that patients 'requiring separate rooms and special attendance, with extras, such as carriage drives, \&c., pay extra rates according to circumstances'. ${ }^{117}$ Once building work was completed, the number of patients in the lunatic branch rose from fifty-five in 1898 to sixty-nine in 1899the largest rise in any one year. The managing committee characterised this growth as a 'great advance' which enabled the hospital 'to deal with a class of patients previously sent elsewhere for treatment'. ${ }^{118}$

Another stark indicator of mounting competition was the decision to advertise. ${ }^{119}$ Both Bloomfield and Stewarts were advertised in the Medical Directories for Ireland, Bloomfield first appearing in 1889 and again in 1898, and Stewarts appearing from 1899. As we shall see, private asylums had been advertising in the Medical Directories from the early nineteenth century, a practice which increased swiftly in the late nineteenth century, pointing towards the economic pressures on the voluntary and private sectors. In 1901, Bloomfield's managing committee circulated copies of an 'illustrated prospectus' for Bloomfield and Swanbrook 'with the view of making Bloomfield better known'. ${ }^{120}$ 
The annual reports for voluntary asylums were also used as a means of publicity. In them, managing committees not only reassured subscribers their charity was being put to good use but also assuaged any fears concerning abuses, providing a transparency that private asylums lacked. The guarantee of a socially significant readership-the asylum's philanthropic subscribers-meant that annual reports were an excellent platform for stimulating sympathy, sensitivity and, perhaps most importantly, awareness among those who could afford to donate. Stewarts' annual reports only came to be utilised in this way from the 1890s. Previously they had contained only snippets about the workings of the asylum branch. Yet, by 1899, Stewarts' terms of admission read almost like an advertisement for the asylum: 'It is situated within a handsome demesne of nearly 100 acres in a most salubrious district and commands beautiful views.' ${ }^{121}$ Voluntary asylums were now very much part of the institutional marketplace.

\section{'The Trade In Lunacy’? 122}

It is difficult to escape associations with the trade in lunacy when exploring the history of private asylums. This model, which traditionally emphasises proprietors' profiteering over any real concern for patient welfare, immediately distinguishes private asylums from their public or voluntary counterparts. In the English context, Parry-Jones has largely dismissed derogatory public characterisations of private asylums as sensationalist and prejudiced. ${ }^{123}$ Yet these institutions did generate profits and were often a lucrative commercial enterprise for medical men. ${ }^{124}$ This also held in Ireland, so long as proprietors attracted a wealthy clientele, competed well with other establishments and weathered any economic downturns that arose. However, given the development of the private sector prior to the introduction of the Poor Law, parishes did not maintain destitute lunatics or idiots in private asylums, as was the tendency in England. As a result, a 'trade in lunacy' on the scale of its English equivalent did not exist in Ireland's relatively modest network of private asylums. ${ }^{125}$

Like any business venture, establishing a private institution entailed personal financial risk. This was true for Drs. John Eustace and Richard Grattan, whose partnership contract for the joint ownership of Hampstead in 1826 highlights the magnitude of their investment: 
we each agree to pay one half of the expenses which shall be incurred in any manner for conducting the said Establishment and we likewise agree to divide equally between us whatever profit may arise from said Establishment and in all matters relating to or connected with the management of the said Establishment we consider ourselves equally bound and responsible. ${ }^{126}$

If the venture proved a failure, the doctors would have been liable for any debts incurred. While Grattan left the partnership in 1830, for Eustace, Hampstead House was a success and in 1857, his sons John II and Marcus joined him. ${ }^{127}$

The continued success and prosperity of private asylums was dependent on the proprietor's personal reputation and the public confidence he held. ${ }^{128}$ Eustace was a Quaker who had begun his career as a visiting physician to Bloomfield in 1815 . He also had a private practice and from 1822 was a temporary physician to the Cork Street Fever Hospital in Dublin. ${ }^{129}$ The 1842 Act favoured medical men as private asylum proprietors. If the proprietor was not a physician, surgeon or apothecary, the licensed house in question must be visited by a 'medical man' at least every fortnight who would sign a statement of health for each patient, which was entered into the asylum's books for the inspectors' perusal. ${ }^{130}$ The position in Britain was similar, where lay proprietors were often considered 'more likely to be corrupt, negligent and avaricious than their medical colleagues'.131 Advertisements for private asylums in England and Ireland therefore often specified the qualifications of their proprietors. ${ }^{132}$ For example, one advertisement for Hampstead House simply listed the names of the proprietors and the consulting physician, their qualifications and the cost of maintenance, implying the doctors' reputations alone superseded any need for further embellishment (see Fig. 3.1).

Because patient fees were the sole source of funding for private institutions, they tended to be high. Between 1820 and 1860, the average private asylum fee was approximately $£ 80$ per annum. ${ }^{133}$ Minute

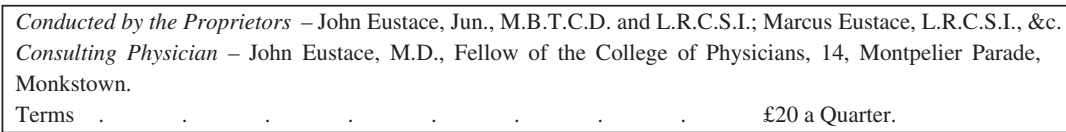

Fig. 3.1 Advertisement for Hampstead House, Glasnevin, Dublin, 1858. Source Medical Directory for Ireland, 1858 
books for Hampstead offer the earliest indication of fees in the nineteenth century. From its opening in 1826 until 1831, the lowest rate was fifty-two guineas $(£ 5412 s)$ per annum. ${ }^{134}$ For the first thirty-four patients admitted, the average annual fee was $£ 61$. Not unlike patients in voluntary asylums, several patients were maintained at less than the minimum rate of maintenance (almost half). Fees varied greatly from $£ 26-£ 100$ per annum plus an extra $£ 40$ where a servant was to accompany the patient. Evidence supplied by private asylum proprietors at the 1857-1858 inquiry demonstrates that this wide variation in fees continued. By then, the lowest fees at Hampstead were $£ 40$ per year and the highest $£ 150$, excluding patients kept at low rates on charitable grounds. Despite the 'low rate' of maintenance offered, John Eustace II (1827-1899) informed the commissioners that he had been obliged to refuse 'patients of the middle class' who were unable to pay sufficient sums. He reasoned that these cases were probably taken into other private asylums, at low rates of maintenance, or into the district asylum. ${ }^{135}$ Surprisingly, Eustace did not apparently consider that voluntary asylums received these patients, though he may have included these under 'private' asylums.

Several other private establishments received patients at lower rates. Maintenance fees at Eagle House in Finglas, Dublin, ranged from £25$£ 100$. Fees at Belleview in Dublin also varied widely. While Belleview's proprietor, Richard Gregory, claimed that one patient was maintained at the staggering sum of $£ 270$ per annum, he stated that other patients were accommodated at as low as $£ 25$. Despite this disparity, Gregory maintained that the 'average' rate was $£ 80$ per annum, revealing that fees at Belleview were not dissimilar to most other Irish private asylums during the period. Nonetheless, Gregory and other proprietors claimed to have received a 'good many' applications for admissions at reduced sums, who could not be accommodated. ${ }^{136}$ Meanwhile, fees at Hartfield in Dublin ranged from $£ 20-£ 120$. Hartfield's proprietor, Dr. William Lynch, remarked that only one patient paid this low rate; the lowest charge was ordinarily thirty guineas $(£ 31 \quad 10 s)$ and even then, very few patients were maintained at this. ${ }^{137}$ As Chap. 2 demonstrated, the private asylums that offered lower rates were eventually criticised for their inability to provide adequate care for their patients.

At the other end of the fee scale, Farnham House in Dublin charged between $80(£ 84)$ and $120(£ 126)$ guineas per year. Where 'special 
attendance' was deemed necessary, patients were charged $£ 50$ per quarter (£200 p.a.). ${ }^{138}$ The practice of listing maintenance fees in guineas underscored the exclusivity of institutions like Farnham House, in an era when items and services intended for the wealthier classes were often priced in this style. ${ }^{139}$ A series of advertisements for Farnham House, published in Medical Directories during the 1860s, further supports this, in proclaiming 'none but patients of respectability admitted'. ${ }^{140}$ Yet even asylums that clearly espoused an exclusive character 'very often' received applications to admit patients at lower rates. Farnham House's proprietor, Dr. James Duncan, stated that these applicants would generally go to St Patrick's Asylum or 'some other such establishment'. While Duncan claimed there existed 'at large' a considerable proportion of lunatics above the rank of pauper who could not afford to pay the lowest sum in a private asylum, he also cautioned that some who could pay would attempt to secure reduced rates, or even free accommodation, if possible. ${ }^{141}$

After the 1860s, there is little evidence concerning Irish private asylum fees. An account book for Hampstead and Highfield in the 1890s sheds some light on the fees charged in that decade, detailing the monthly contributions made towards patients' maintenance. Figures for individual patients differed from year to year, suggesting payments were made at irregular intervals. The presence of very small amounts, as well as large ones, implies patients were also charged for extras. The figures listed suggest that the yearly amount contributed per patient ranged from $£ 39$ to $£ 585$. However, more than $90 \%$ of fees were over $£ 100$ and the average fee during this period was $£ 215$ per annum. ${ }^{142}$

In 1894, the lunacy inspectors reported that the maintenance fees at Lindeville in Cork ranged from $£ 60$ to $£ 150 .{ }^{143}$ This isolated reference suggests that other private asylums also continued to admit patients on a graded scale of maintenance. Advertisements during this period indicate that proprietors were willing to negotiate fees with the families of potential patients, a practice which reflected the increased competition with voluntary asylums in this era. Several advertisements directed applications to be made to the proprietor or resident superintendent, who would furnish the relatives and friends of potential clients with a prospectus, terms of pay and admission forms. ${ }^{144}$ Those wishing to apply for admission to Hampstead and Highfield could simply call into the offices of the Drs. Eustace, located conveniently on Grafton Street in Dublin's city centre. ${ }^{145}$ 
Irish private asylum fees were high compared with England. This is striking, given that the cost of living, as well as wages, in Ireland was lower than in England. Parry-Jones has estimated that, in 1850, fees at a typical middle-class establishment ranged from 15 shillings to two guineas per week (approx. £39-£109 p.a.). ${ }^{146}$ England also possessed private asylums that charged high rates. At Ticehurst, patients were charged between $£ 50$ and $£ 500$ per annum, or an average of $£ 150$ in 1845 , a figure that tripled to between $£ 400$ and $£ 500$ by 1875. MacKenzie attributes this rise to the 'general increase in retail prices associated with the growth of consumerism generated by the expansion of the middle classes in the 1850s-1870s'. After 1875, fees in the middle range plateaued, while those on the higher scale continued to rise. ${ }^{147}$ It is unclear whether private asylum fees in Ireland underwent a comparable increase during the mid-Victorian period. However, many proprietors may have been forced to reduce fees in the latter part of the century due to the economic depression that began in Ireland in 1879 and lasted until the middle of the 1890s. Indeed, MacKenzie suggests that a combination of economic downturn and therapeutic pessimism impacted negatively on business at Ticehurst. Although fees at that asylum remained at a similar level, during the last decades of the nineteenth century patients obtained larger lodgings, suggesting better value for money. ${ }^{148}$ As with voluntary asylums, increased advertising for Irish private asylums in the Medical Directories indicates a mounting need to generate more business. While in the 1860s only one or two proprietors advertised there, by the turn of the century, the majority were doing so.

By the 1880s, several private asylums were in financial difficulty. The lunacy inspectors frequently referred to 'the depressed state of the country', noting an increase in applications for private patients to be transferred to public institutions. ${ }^{149}$ The inspectors also referred to 'an irregular system of payment, even of small stipends'. ${ }^{150}$ Difficulties in obtaining maintenance fees were not confined to the late nineteenth century. During the 1857-1858 inquiry, private asylum proprietors expressed frustration at being unable to recover payment from patients' relatives. Duncan informed the commissioners that in one or two cases he had received neither clothing nor maintenance fees and was obliged to maintain some patients at his own personal cost. These cases cost him from 20 to 30 guineas per quarter $\left(£ 84-£ 126\right.$ p.a. each). ${ }^{151}$

During the 1857-1858 commission, Hartfield's proprietor, Dr. William Lynch, outlined his difficulties in obtaining Chancery patients' maintenance 
fees. The committees established by Chancery to manage patients' affairs allegedly made a 'hard bargain with the asylum proprietor and at times would not pay regularly', even when patients had been awarded a maintenance of about $£ 150$ per annum. In these cases, Lynch claimed he sustained heavy losses. Fees were not paid regularly during the patient's residence in the asylum and, following the patient's death, were generally not paid at all. ${ }^{152}$ In another instance, Lynch complained, a female patient with 'upwards of $£ 2000$ in the bank and a nice property besides' was neglected by her Chancery committee. She was reportedly 'in a most disgraceful state' and the cloak eventually supplied for her would have 'scarcely fit a child'. Although Lynch stated he had written frequently to the Committee, arrears of maintenance were still due to him for this patient. ${ }^{153}$

The fact that these proprietors kept patients at their own expense might be attributed to motives of philanthropy. In England, certain private asylum proprietors were 'remarkably charitable', keeping some patients at especially low rates or allowing them to remain free of charge. ${ }^{154}$ It is equally possible, however, that proprietors were anxious to safeguard their asylums' reputation of care. The 1842 Act offered no protection for proprietors who were unable to recover maintenance fees. While suing for fees was an option, the legal costs probably deterred proprietors from entering a conflict which might impact negatively on their own and the institution's reputation. In 1855, when Lynch attempted to sue for outstanding fees, the expense of the application and legal proceedings equalled the balance due to him. ${ }^{155}$ While these legal proceedings do not appear to have attracted any media attention, the matter was listed under 'insolvent debtors' in the Nation newspaper and both Lynch and his asylum were explicitly named. ${ }^{156}$

Given the futility of attempts to recover arrears legally, it is notable that proprietors did not simply expel patients whose fees were not paid. When the governors at St Patrick's Hospital confronted comparable difficulties in the 1870s, they resolved to remove any patient who was more than six months in arrears. However, Malcolm argues that the board seemed hesitant to carry out this threat, presenting multiple reasons for their reluctance:

Expulsion was not a pleasant procedure and usually meant the end of hope of recovery of arrears. Also frequently patients had been in the hospital for decades and the relatives or guarantors who had originally signed the bond for the fees were dead or untraceable ... In these circumstances 
the governors did not have any very strong legal grounds for demanding payment. If families flatly refused to accept elderly relatives, whom they may never have even seen, the hospital authorities could hardly leave the patients on their doorstep. ${ }^{157}$

Malcolm also suggests the transfer of patients to either the Richmond asylum or the workhouse would reflect poorly on the reputation of a supposedly charitably institution, ${ }^{158}$ although this may have been less concerning for those conducting private enterprises. Nonetheless, whether for motives of altruism or for fear of attracting hostility from patients' relatives and potentially putting off new clients, both Duncan and Lynch demonstrated a similar hesitance in discharging patients who were in arrears. Given the nature of record keeping for the private asylums studied, it is impossible to ascertain either how many patients were not supported financially or for how long.

The boundaries between who could afford voluntary and private asylum care and who could not became further blurred after the establishment of Belmont Park in Waterford in 1884 and the St John of God's in Dublin in 1885. The 1884 prospectus for the St John of God's specified fees of one guinea, $£ 110 s$ and $£ 2$ per week ( $£ 5412 s, £ 78$ and $£ 104$ p.a.) for permanent boarders in good health and between $£ 2$ and $£ 3$ per week (£104 and $£ 156$ p.a.) for the sick. These rates included the 'ordinary requirements' of a separate furnished bedroom, general sitting room, billiard and smoking room, board but no stimulants, ordinary medical attendance, ordinary nursing and attendance by Brothers. Further private arrangements could be made to have special attendance. Extras included additional consultations, medicines, stimulants and the washing of boarders' linen. ${ }^{159}$ These rates correspond to the lunacy inspectors' statement that the hospital offered low rates for middle-class patients. Although the inspectors referred to St John of God's as a private asylum, it is probable, given the religious ethos of the hospital's founders, that it was not kept for profit. In fact, the hospital's only distinguishing feature from the voluntary asylums was that it did not provide for charity patients. The religious and philanthropic elements of St John of God's was clearly popular with prospective clients, shown by the asylum's dramatic expansion in the twentieth century. As Chap. 2 argued, this meant that asylums like St John of God's created a bridge between the cost of accommodation in a voluntary asylum and a more expensive private establishment. 


\section{Length AND OUTCOME OF STAY}

As we have seen, there was some debate over whether private asylums offered a greater likelihood of curing insanity than the district sector. Those attempting to appease contemporary public alarm over wrongful or prolonged confinement in private asylums maintained that it was in the financial interest of proprietors to cure as many patients as possible in as short a time as possible. The strategy of treating insanity both promptly and successfully was also aspired to in English contexts, where, as Parry-Jones has found, it could serve as an 'effective advertisement' for a private asylum. ${ }^{160}$ Critics' claims that private asylums provided little more than custodial care, rather than cure, were therefore often misleading. ${ }^{161}$ In reality, those investing high sums in the care of their relatives would have anticipated fast, effective results. When such an outcome was not forthcoming, patients were frequently removed to alternative places of care.

Evidence abounds that private asylums tended to achieve high rates of discharge and even cure for private patients. Between 1826 and 1867, most patients whose length of stay at Bloomfield $(63.5 \%)$ and Hampstead (69.9\%) is known stayed for less than one year. These figures are almost identical to those for the two Oxfordshire private asylums at Hook Norton and Witney (62\% and 66\% respectively) and higher than the York Retreat (approx. $40-50 \%$ ) in this period. ${ }^{162}$ Digby has interpreted such high patient turnover as evidence against contemporary anxieties about the silting up of asylums with chronic, long-stay cases, while Parry-Jones contends that it goes some way towards refuting accusations of the prolonged confinement of private patients for corrupt motives including financial gain. ${ }^{163}$ These arguments also apply in the Irish context. As shown in Table 3.5, from 1868 to 1900, the majority of patients admitted to the asylums studied spent short periods there. Not unlike patients admitted to the York Retreat, ${ }^{164}$ Irish private asylum patients, in particular, tended to stay for less than one year $(67.1 \%)$, as did twothirds of male and over one-half of female paying patients admitted to the district asylums. This compares favourably with district asylums in this period. For example, in her study of the Armagh, Belfast, Omagh and Sligo asylums, Malcolm has found that at most, half of the patients admitted stayed for twelve months or less. ${ }^{165}$ Meanwhile, longer stays of five years or more were slightly less common among paying patients than total district asylum populations. ${ }^{166}$ 
Table 3.5 Known length of stay for patients admitted to the district, voluntary and private asylums studied, 1868-1900a

\begin{tabular}{lllllllllll}
\hline & \multicolumn{3}{c}{ District } & \multicolumn{3}{c}{ Voluntary } & \multicolumn{3}{c}{ Private } \\
\hline & $\mathrm{F}(\%)$ & $\mathrm{M}(\%)$ & $\mathrm{T}(\%)$ & $\mathrm{F}(\%)$ & $\mathrm{M}(\%)$ & $\mathrm{T}(\%)$ & $\mathrm{F}(\%)$ & $\mathrm{M}(\%)$ & $\mathrm{T}(\%)$ \\
Less than & 52.9 & 66.3 & 60.9 & 59.4 & 56.3 & 58.3 & 62.2 & 67.6 & 67.1 \\
1 year & & & & & & & & & \\
1-5 years & 22.8 & 17.0 & 19.3 & 22.3 & 22.0 & 22.2 & 20.3 & 20.0 & 20.0 \\
5-10 years & 9.1 & 4.9 & 6.6 & 7.0 & 10.8 & 8.4 & 6.8 & 3.0 & 3.4 \\
10 + years & 15.2 & 11.8 & 13.2 & 11.3 & 10.8 & 11.1 & 10.8 & 9.4 & 9.6 \\
Total & 100.0 & 100.0 & 100.0 & 100.0 & 100.0 & 100.0 & 100.0 & 100.0 & 100.0 \\
$N=$ & 276 & 407 & 683 & 471 & 277 & 748 & 74 & 700 & 774 \\
\hline
\end{tabular}

Compiled from Belfast, Ennis, Enniscorthy, Richmond, Stewarts, Bloomfield, St John of God's, Hampstead and Highfield admissions registers

'The first admission to St John of God's was in 1885

The likelihood of dying in the asylum was less for private and voluntary asylum patients than for paying patients sent to district asylums. Like patients at the Witney asylum, in the earlier period, one-tenth of patients admitted to Hampstead and Bloomfield died in the asylum. ${ }^{167}$ While a larger proportion of Hook Norton patients (21.9\%) died there, Parry-Jones has related this disparity to the reception of paupers to this institution, among whom a number were admitted suffering with chronic or intractable physical and mental conditions. ${ }^{168}$ This reasoning also explains the differences in mortality rates in Irish asylums. While between 1868 and $1900,20.1 \%$ of patients admitted to the private asylums and $30 \%$ of those admitted to voluntary asylums died there, $40.9 \%$ of paying patients admitted to the district asylums suffered a similar fate (see Table 3.6). References to poor bodily health were far more frequent in the case notes for paying patients admitted to Enniscorthy and Richmond than to the voluntary and private asylums studied. In fact, district asylum paying patients seemed especially vulnerable, even compared with some 'pauper' populations, such as the Sligo asylum, where onethird of admissions between 1855 and 1893 died. ${ }^{169}$ Yet, while death rates among the district asylum paying patients decreased slightly over the period examined, Finnane has found that, by 1901, nearly half of district asylum patients were dying. ${ }^{170}$

The most notable difference in outcome in the Irish context was the proportion of cures, which was reportedly significantly higher in Irish 
private asylums than in English ones. Between 1826 and 1867, half of patients admitted to Bloomfield and Hampstead were discharged cured and a further fifth improved or relieved. By comparison, 27\% of private patients admitted to Hook Norton, 35\% to Witney and between 35 and $44 \%$ to the York Retreat were 'cured' during the same period. ${ }^{171}$ As was the trend in other asylums, most of those recorded as cured were released within one year of admission $(78.7 \%$ at Bloomfield and $82.1 \%$ at Hampstead). In the later period, almost half of the private asylum patients were discharged cured, while one in three were discharged from the voluntary and district asylums under this description (see Table 3.6). In her discussion of patient outcomes at Ticehurst, MacKenzie has challenged Scull's contention that private asylum cure rates were 'abysmally low', showing that some $60-80 \%$ of admissions were discharged, while 16-39\% were discharged recovered. However, as MacKenzie concedes, this was low compared with recovery rates at less expensive asylums including the Retreat, lending some credence to Scull's argument that 'money could not buy health'. ${ }^{172}$ At the Retreat during the same era, recovery rates were roughly one-third of admissions. ${ }^{173}$ This reveals that

Table 3.6 Known outcome of stay for patients admitted to the district, voluntary and private asylums studied, $1868-1900^{\mathrm{a}}$

\begin{tabular}{|c|c|c|c|c|c|c|c|c|c|}
\hline & \multicolumn{3}{|c|}{ District Asylums } & \multicolumn{3}{|c|}{ Voluntary Asylums } & \multicolumn{3}{|c|}{ Private Asylums } \\
\hline & $\mathrm{F}(\%)$ & $\mathrm{M}(\%)$ & $\mathrm{T}(\%)$ & $\mathrm{F}(\%)$ & $\mathrm{M}(\%)$ & $\mathrm{T}(\%)$ & $\mathrm{F}(\%)$ & M (\%) & $\mathrm{T}(\%)$ \\
\hline $\begin{array}{l}\text { Cured/ } \\
\text { Recovered }\end{array}$ & 31.6 & 33.4 & 32.7 & 33.1 & 31.2 & 32.4 & 46.1 & 48.6 & 48.3 \\
\hline $\begin{array}{l}\text { Improved/ } \\
\text { Relieved }\end{array}$ & 17.4 & 20.0 & 18.9 & 26.9 & 20.8 & 24.7 & 19.7 & 13.4 & 14.1 \\
\hline $\begin{array}{l}\text { Not } \\
\text { Improved/ } \\
\text { Not } \\
\text { Relieved }\end{array}$ & 6.7 & 7.9 & 7.4 & 13.3 & 12.3 & 12.9 & 0.0 & 3.8 & 3.4 \\
\hline $\begin{array}{l}\text { Not } \\
\text { Cured/Not } \\
\text { Recovered }\end{array}$ & 0.0 & 0.0 & 0.0 & 0.0 & 0.0 & 0.0 & 10.5 & 5.6 & 6.1 \\
\hline Died & 44.3 & 38.6 & 40.9 & 26.7 & 35.7 & 30.0 & 23.7 & 28.6 & 28.1 \\
\hline Total & 100.0 & 100.0 & 100.0 & 100.0 & 100.0 & 100.0 & 100.0 & 100.0 & 100.0 \\
\hline$N=$ & 253 & 365 & 618 & 465 & 269 & 734 & 76 & 640 & 716 \\
\hline
\end{tabular}

Compiled from Belfast, Ennis, Enniscorthy, Richmond, Stewart's, Bloomfield, St John of God's, Hampstead and Highfield admissions registers

aThe first admission to St John of God's was in 1885 
Irish private asylum patients had better chances of being cured, or at least of being described as cured, than their English counterparts. Irish voluntary and district asylums, meanwhile, were keeping pace with, if not outperforming, the renowned York Retreat when it came to cure rates for paying patients.

Of course, discharge did not always signal the end of institutionalisation for patients. Of the 2368 patients admitted to the asylums studied between 1868 and 1900, 284 (12.0\%) were identified as readmissions. In contrast to Malcolm's finding that patients readmitted to district asylums were commonly committed several times before being committed permanently to die in the institution, the outcome for readmissions in this study tended to be more positive than that for first admissions. ${ }^{174}$ Overall, half (50.8\%) were cured compared with $36.3 \%$ of first admissions, while fewer died $(22.7 \%$ of readmissions; $33.9 \%$ of first admissions).

As Cox has pointed out, discharge rates have been largely neglected in the Irish context. ${ }^{175}$ Her finding that $42.8 \%$ of admissions to the Carlow asylum between 1832 and 1922 were discharged 'recovered' thus provides the only point of reference. ${ }^{176}$ While recovery rates for paying patients admitted to the district and voluntary asylums are comparably low, the proportion of patients discharged as 'relieved' is much higher (18.9 and $24.7 \%$ respectively) than the $6.9 \%$ at Carlow. ${ }^{177}$ Moreover, given the higher death rates in district asylums, it is plausible that the private and voluntary asylums tended to produce more cures or partial improvement than the district ones.

The large proportion of those discharged 'relieved', 'not relieved' or 'not recovered' in this study suggests that the families of fee-paying patients tended to withdraw them prematurely, probably to lessen the financial burden of asylum care. ${ }^{178}$ As we have seen, families often went to great lengths to pay for relatives' care in these institutions, while for many a fast recovery was all their limited means could afford. This echoes Walsh's suggestion that relatives viewed asylums as a resource to be used when needed. ${ }^{179}$ For families with greater disposable funds who were displeased with the outcome of care in one asylum, the institutional marketplace offered many alternatives.

The transfer of patients to other institutions was not uncommon. Despite wide disparities in maintenance fees and standard of accommodation, the boundaries between district, voluntary and private asylums were extremely permeable and patients were transferred between the three sectors. Reasons for transfer varied. Understandably a change in 
economic circumstances could prevent continued accommodation at a private or voluntary asylum and result in a patient being moved to an institution charging lower rates. Although data on transfers in the asylum records is patchy, case notes for both Stewarts and Bloomfield patients, resident during the 1890 s, contain a field marked 'where and when previously under care', allowing for some analysis. The information provided also takes into account patients who had been discharged from one institution and then later admitted to another.

The Stewarts case notes reveal that a number of patients admitted there had previously spent time in district asylums. This cohort tended to pay lower sums $(£ 30-£ 60$ p.a.) in the voluntary asylums, although not exclusively. For example, three women were transferred from Richmond, where they had been contributing $£ 14, £ 15$ and $£ 24$ $17 s .8 d$. per annum respectively, to Stewarts, where they were charged between $£ 50$ and $£ 52$ per annum each. However, patients admitted to Bloomfield and Stewarts were most likely to be transferred from a private asylum, suggesting reduced circumstances or simply decreased confidence in the efficacy of private asylum care were reasons for the move. Patients transferred from private asylums usually paid between $£ 50$ and $£ 100$ at the voluntary asylums, although some were maintained at higher rates on a par with private asylum fees. For example, four years after his discharge from Hampstead House, Cecil W.W., a twenty-two year-old, single, ship-builder's apprentice was admitted to Bloomfield in September 1896 . There he was charged $£ 160$ per annum but after one year it was recorded that Cecil had 'been visited lately a good deal by his sisters and uncle, and yesterday was removed to Dr. Eustace's'. ${ }^{180}$ Similarly, Henrietta Sophia M., a forty year-old single woman was sent by her brother to Bloomfield in April 1893 at $£ 100$ per annum. She had previously been a patient in the Crichton Royal Institution in Dumfries from September 1891 to 1892 . This case was not unusual. Several voluntary asylum patients had previously been accommodated in asylums in Britain, including Morningside, West Riding and Crichton. These patients tended to pay average rates in the voluntary asylums, lending weight to the lunacy inspectors' claims that wealthier families often chose to send relatives to Britain where private asylums charged more competitive rates. ${ }^{181}$ After she was discharged from Crichton, Henrietta had stayed 'in various places' where she was reportedly 'excited, crying much and talking incessantly of herself and her misfortunes'. Henrietta gave an account of her experience at Crichton: 
Whenever I see her she talks about herself constantly, saying she is quite sane and that her troubles and the bad treatment she says she got at Dumfries have made her nervous and excited ... Is very unhappy. Says she was ruined by the cruelty she received in Dumfries and that she needed lively and happy society and was just improving when sent here.

While in Bloomfield, the physician reported that:

Some days she stays in bed. Others gets up, but would not go out except once for a few minutes. She says she cannot work, read, or do anything as long as she is here, and that the sight of a lunatic would make her die... She cries loudly. She tears her fingers till they bleed and is dirty in habits, wetting her things frequently. She wants to leave, but when at liberty before coming here she says she was in much the same state as now.

By November, it was reported that Henrietta was to be moved to a private asylum in Finglas. ${ }^{182}$ In these instances, the high fees paid for Cecil and Henrietta confirm that families with considerable disposable income had the luxury of selecting between institutions.

\section{Conclusions}

This chapter has shown that district, voluntary and private asylums operated in an institutional marketplace. Within this marketplace, families held the purse strings. Of the three groups, relatives negotiating with district asylums exerted the least influence and were subject to thorough and sometimes intrusive investigations into their financial circumstances. Although the lunacy inspectors criticised asylum boards for failing to identify patients with means, this chapter has revealed that the boards went to great lengths to identify those who could afford to contribute. The boards did, however, demonstrate compassion for those genuinely in need of relief, as these patients were legally entitled to accommodation based on their mental condition rather than their ability to pay fees. This conforms to Cox's findings in the context of the Carlow and Enniscorthy districts. ${ }^{183}$ Ultimately, however, and as Cox has found for Carlow and Enniscorthy, the proportion of revenue generated from patient contributions was small. ${ }^{184}$

Families possessed of greater means had more influence in the marketplace and the managing bodies of voluntary and private asylums were 
compelled to tailor accommodation and maintenance fees to the needs of their clientele. This eventually resulted in competition between the voluntary and private sector in the 1890 s, as evidenced by the decision of Stewarts' and Bloomfield's managing committees to provide more expensive and luxurious accommodation and to advertise. This resulted in part from the establishment of less expensive private asylums including St John of God's. It was also a consequence of the economic downturn of the 1880s and 1890s: families who might once have availed of private care were now forced to consider less expensive options. These developments in turn affected private asylums. Although the lunacy inspectors frequently criticised private asylum proprietors who charged lower fees, the combined effects of the economy and competition from voluntary asylums meant that they were increasingly under threat of closure. This is in spite of the higher proportion of patients cured at the private asylums studied, which would have sat well with contemporary private asylum proprietors anxious to guard against accusations of wrongful or over-lengthy confinement. While in the English context Parry-Jones has characterised private asylum proprietors as 'remarkably charitable' for charging some patients low rates, this chapter has highlighted that, at least in Ireland, proprietors were anxious to safeguard their asylums' reputation of care. ${ }^{185}$ Thus, by 1900 , many of the more prestigious asylums had shifted their target market to encompass less affluent socio-economic groups.

\section{Notes}

1. Cox (2012), pp. 97-132, 148, 154-159, Wright (1998), Finnane (1981), pp. 175-220; Walton (1979-1980), pp. 1-22.

2. Cox (2012), p. 23.

3. Malcolm has traced similar developments in the history of St Patrick's: Malcolm (1989), pp. 118-120.

4. Smith (1999a), (1999b). See also Melling and Forsythe (2006).

5. W.S. Studdert to R.P. Gelston, 26 Jul. 1888 (CCA, Our Lady's Hospital, OLl/7 Letter 1489).

6. For example, James K. to R.P. Gelston, 10 Jan. 1893 (CCA, Our Lady's Hospital, OLl/7 Letter 1883).

7. For example, J. Coffey Ryan to R.P. Gelston, 18 Jun. 1894 (CCA, Our Lady's Hospital, OLl/7 Letter 2025b). For more on the role of medical officers in the Irish medical dispensary system see Cox (2010), pp. $57-78$. 
8. Fortieth Report of the Inspectors of Lunatics (Ireland), H.C. 18901891, p. 521.

9. Minute Books (CCA, Our Lady's Hospital, OLl/1); Medical Superintendent Memorandum Books (WCC, St Senan's Hospital, Enniscorthy); Minutes of the Governors of Enniscorthy District Lunatic Asylum (WCC, St Senan's Hospital, Enniscorthy).

10. Medical Superintendent Memorandum Books, 1868-1889 (WCC, St Senan's Hospital, Enniscorthy, p. 239).

11. For example, Rough Minute Book, 1867-1871 (CCA, Our Lady's Hospital, OLl/24/4, 14 Sep. 1871); Minute Book, 1878-1881 (CCA, Our Lady's Hospital, OLl/1/2, pp. 246, 378); Minute Book, 18881891 (CCA, Our Lady's Hospital, OLl/1/5, p. 216).

12. Some correspondence books for this period are not extant.

13. 38 \& 39 Vic., c. 67 , s. 16.

14. For example, Fred G. Kerin, Solicitor to RMS, Ennis, 26 Aug. 1898 (CCA, Our Lady's Hospital, OL1/7 Letters 2504a and 2504b).

15. For example, Medical Superintendent Memorandum Book, 1868-1889 (WCC, St Senan's Hospital, Enniscorthy, pp. 48, 389, 436), 38 \& 39 Vic., c. 67 , s. 16 .

16. Minute Book No. 13, 1872-1877 (NAI, Richmond District Lunatic Asylum, p. 80).

17. Ibid., p. 343.

18. Minutes of the Governors of Enniscorthy District Lunatic Asylum, 1883-1898 (WCC, St Senan's Hospital, Enniscorthy, pp. 16, 50).

19. Minute Book No. 14, 1877-1881 (NAI, Richmond District Lunatic Asylum, pp. 185-186).

20. For example, Minute Book, 1874-1880 (CCA, Our Lady's Hospital, OLl/1/1, p. 218).

21. Minute Book, 1880-1885 (CCA, Our Lady's Hospital, OLl/1/3, p. 331).

22. Michael B. to Governors of the Lunatic Asylum, Ennis (CCA, Our Lady's Hospital, OLl/7 Letter 1657); Minute Book, 1888-1891 (CCA, Our Lady's Hospital, OLl/5, p. 286).

23. Michael B. to the Governors of the Lunatic Asylum Ennis, 13 Jun. 1890 (CCA, Our Lady's Hospital, OLl/7 Letter 1657).

24. See Minute Book, 1898-1902 (CCA, Our Lady's Hospital, OLl/1/8, pp. 17, 27, 216); Letter from J. Garry to Dr. O’Mara, 21 Dec. 1899 (CCA, Our Lady's Hospital, OLl/7 Letter 2706).

25. $38 \& 39$ Vic., c. 67, s. 16.

26. Cox (2012), p. 181.

27. Ibid., p. 182. 
28. Clerk of Union, Workhouse, Tulla to R.P. Gelston, 14 Sep. 1892 (CCA, Our Lady's Hospital, OLl/7 Letter 1857).

29. $38 \& 39$ Vic., c. 67 , s. 9.

30. See Cox (2012), pp. 181-183.

31. Ibid., p. 22.

32. Pat F. to R.P. Gelston, 3 Nov. 1892 (CCA, Our Lady's Hospital, OLl/7 Letter 1866).

33. J. Culligan JP to Ennis District Asylum, 29 Nov. 1894 (CCA, Our Lady's Hospital, OLl/7 Letter 2054).

34. H.S. Land Agency Office, Galway to R.P. Gelston (CCA, Our Lady's Hospital, OLl/7 Letter 2469).

35. Ellen D. to The Secretary, Asylum, Ennis, 3 Dec. 1883 (CCA, Our Lady's Hospital, OLl/7 Letter 984).

36. R.D. O’Brien to R.P. Gelston, 17 Nov. 1888 (CCA, Our Lady's Hospital, OLl/7 Letter 1519).

37. Cox (2012), pp. 99, 102.

38. Henry P.R to Governors of Ennis Asylum, 3 Jun. 1884 (CCA, Our Lady's Hospital, OLl/7 Letter 1045).

39. Henry P.R to R.P. Gelston, 28 May 1888 (CCA, Our Lady's Hospital, OLl/7 Letter 1471); Henry P.R., to R.P. Gelston, 27 Apr. 1889 (CCA, Our Lady's Hospital, OLl/7 Letter 1560).

40. Minute Book, 1870-1882 (PRONI, Purdysburn Hospital, HOS $/ 28 / 1 / 1 / 4$, p. 101).

41. Ibid., p. 111.

42. For example, Medical Superintendent Memorandum Book, 1868-1889 (WCC, St Senan's Hospital, Enniscorthy, p. 198).

43. Medical Superintendent Memorandum Book, 1868-1889 (WCC, St Senan's Hospital, Enniscorthy, p. 176).

44. Minute Book No. 14, 1877-1881 (NAI, Richmond District Lunatic Asylum, p. 206).

45. Cox (2012), p. 22.

46. For example, Ibid., pp. 37-38, 43.

47. For example, Minute Book, 1880-1885 (CCA, Our Lady's Hospital, OLl/l/3, p.158); Minute Book, 1891-1894 (CCA, Our Lady's Hospital, OLl/1/6, p. 213); Minute Book, 1894-1898 (CCA, Our Lady's Hospital, OLl/1/7, pp. 333, 393); Rough Minute Book, 1867-1871 (CCA, Our Lady's Hospital, OLl/2/4, 14 Nov. 1868, 12 Dec. 1868); Minute Book, 1874-1880 (CCA, Our Lady's Hospital, $\mathrm{OLl} / \mathrm{l} / \mathrm{l}, \mathrm{pp} .2,17)$.

48. Cox (2012), p. 20.

49. Finnane (1996), p. 97. 
50. For example, Minute Book, 1870-1882 (PRONI, Purdysburn Hospital, HOS/28/1/1/4, p. 120); Minute Book, 1874-1880 (CCA, Our Lady's Hospital, OLl/1/1, p. 176); Medical Superintendent Memorandum Book, 1868-1889 (WCC, St Senan's Hospital, Enniscorthy, pp. 137, 404, 487, 496).

51. Medical Superintendent Memorandum Book, 1868-1889 (WCC, St Senan's Hospital, Enniscorthy, p. 109).

52. Office of Lunatic Asylums to R.P. Gelston (CCA, Our Lady's Hospital, OLl/7 Letter 1707).

53. Medical Superintendent Memorandum Book, 1868-1889 (WCC, St Senan's Hospital, Enniscorthy, p. 138).

54. Minutes of the Governors of Enniscorthy District Lunatic Asylum, 1883-1898 (WCC, St Senan's Hospital, Enniscorthy, p. 99).

55. For example, Minute Book No. 13, $1872-1877$ (NAI, Richmond District Lunatic Asylum, pp. 134-135).

56. Minutes of the Governors of Enniscorthy District Lunatic Asylum, 1883-1898 (WCC, St Senan's Hospital, Enniscorthy, pp. 138, 145).

57. Ibid., p. 183.

58. For example, Minute Book, 1882-1893 (PRONI, Purdysburn Hospital, HOS $/ 28 / 1 / 1 / 5$, p. 130).

59. Thelma F. to R.P. Gelston, 5 Aug. 1892 (CCA, Our Lady's Hospital, OLl/7 Letter 1845).

60. James K. to Board of Governors, Ennis District Asylum, 13 Jan. 1899 (CCA, Our Lady' Hospital, OLl/7 Letter 2569).

61. R.H. Little, Parish Priest to the Chairman, Board of Governors, District Asylum Ennis, 13 Jan. 1899 (CCA, Our Lady's Hospital, OLl/7 Letter 2569a).

62. Admissions Register (CCA, Our Lady’s Hospital, OL3/1.3).

63. John C. to the Chairman and Board of Governors, Ennis Lunatic Asylum, 9 Feb 1894 (CCA, Our Lady's Hospital, OLl/7 Letter 1987).

64. Minute Book, 1891-1894 (CCA, Our Lady's Hospital, OLl/1/6, p. 336).

65. Denis O'F to the Governors of Ennis District Lunatic Asylum, 1889 (CCA, Our Lady's Hospital, OLl/7 Letter 1536a).

66. Patrick McM to R.P. Gelston, Jan. 1890 (CCA, Our Lady's Hospital, OLl/7 Letter 1624).

67. James W. to R.P. Gelston, Nov. 1889 (CCA, Our Lady's Hospital, OLl/7 Letter 1600); James K. to Board of Governors, Ennis Asylum, May 1892 (CCA, Our Lady's Hospital, OLl/7 Letter 1820).

68. D. Flannery, Parish Priest to R.P. Gelston, 6 Dec. 1889 (CCA, Our Lady's Hospital, OLl/7 Letter 1613). 
69. For more on charity in nineteenth-century Ireland, see Walsh (2005), Luddy (1995); Preston (2004).

70. James Cahir, Parish Priest to RMS Ennis, 7 Apr. 1899 (CCA, Our Lady's Hospital, OLl/7 Letter 2606).

71. James Cahir, Parish Priest to Ennis Asylum, 13 May 1892 (CCA, Our Lady's Hospital, OLl/7 Letter 1815a).

72. Cox (2012), p. 23.

73. In 1888, there were a G.S. Studdert and R.M. Studdert on the Ennis board of governors.

74. W.S. Studdert to R.P. Gelston, 26 Jul. 1888 (CCA, Our Lady's Hospital, OLl/7 Letter 1489).

75. Ibid.

76. See Chap. 1.

77. Cox (2012), p. 19.

78. See Chap. 1.

79. Mary C. to William Daxon, 11 May 1883 (CCA, Our Lady's Hospital, OLl/7 Letter 922).

80. James K. to Asylum, Ennis, 7 Nov. 1889 (CCA, Our Lady's Hospital, Oll/7 Letter 1603).

81. Forty-Second Report of the Inspectors of Lunatics (Ireland), H.C. 1893-1894, p. 369.

82. Forty-Third Report of the Inspectors of Lunatics (Ireland), H.C. 1894, p. 401.

83. Stewart Institution and Asylum Report (Dublin 1871), p. 8; For example, Stewart Institution and Asylum Report (Dublin 1879), p. 19; Stewart Institution and Asylum Report (Dublin 1884), p. 16.

84. Malcolm (1989), pp. 118-120.

85. Stewarts was described as an 'Asylum for Lunatic Patients of the Middle Classes' from at least 1871, in the first extant Annual Report until 1881, when it was changed to 'Asylum for Lunatic Patients'. Stewart Institution and Asylum Report (Dublin 1871), (Dublin 1881).

86. Stewart Institution and Asylum Report (Dublin 1872), p. 17.

87. Stewart Institution and Asylum Report (Dublin 1871).

88. Stewart Institution and Asylum Report (Dublin 1871).

89. Stewart Institution and Asylum Report (Dublin 1873), p. 5.

90. Stewart Institution and Asylum Report (Dublin 1874), p. 5; Stewart Institution and Asylum Report (Dublin 1878), p. 5.

91. Patient Accounts Book (Stewarts, Stewarts Patients' Records).

92. MacKenzie (1992), p. 130.

93. Suzuki (2006), p. 121.

94. Annual Report of the State of the Retreat (Dublin 1814), p. 6.

95. Annual Report of the State of the Retreat (Dublin 1852), p. 7. 
96. Annual Report of the State of the Retreat (Dublin 1863), pp. 8-9.

97. The Stewart Institution and Asylum Report (Dublin 1884), p. 16.

98. The Stewart Institution and Asylum Report (Dublin 1896), p. 19.

99. Cox (2012), pp. 97-132.

100. Melling and Forsythe (2006), p. 146.

101. See Marland (2004).

102. Stewart Institution and Asylum Report (Dublin 1886), p. 17.

103. Stewart Institution and Asylum Report (Dublin 1887), p. 16.

104. Stewart Institution and Asylum Report (Dublin 1885), p. 16.

105. Busfield (1986), p. 176.

106. Annual Report of the State of the Retreat (Dublin 1849), p. 6.

107. Annual Report of the State of the Retreat (Dublin 1856), p. 9.

108. Annual Report of the State of the Retreat (Dublin 1864), p. 5; Annual Report of the State of the Retreat (Dublin 1865), p. 13.

109. Stewart Institution and Asylum Report (Dublin 1888), p. 17.

110. Stewart Institution and Asylum Report (Dublin 1885), p. 16; Stewart Institution and Asylum Report (Dublin 1886), p. 17.

111. Stewart Institution and Asylum Report (Dublin 1886), p. 17.

112. Stewart Institution and Asylum Report (Dublin 1891), p. 18.

113. Ibid., p. 18.

114. Stewart Institution and Asylum Report (Dublin 1893), p. 20.

115. Stewart Institution and Asylum Report (Dublin 1896), p. 23.

116. Stewart Institution and Asylum Report (Dublin 1895), p. 25.

117. Stewart Institution and Asylum Report (Dublin 1897), pp. 1, 9.

118. Stewart Institution and Asylum Report (Dublin 1899), pp. 21-22.

119. Parry-Jones has surveyed printed advertisements for private asylums in England see Parry-Jones, 1972, pp. 102-111.

120. Annual Report of the State of the Retreat (Dublin 1901), pp. 5-6.

121. Stewart Institution and Asylum Report (Dublin 1899), p. 9.

122. Parry-Jones (1972).

123. For a full discussion of the 'trade in lunacy' in eighteenth- and nineteenth-century England and Wales, see Parry-Jones (1972).

124. MacKenzie (1992), Parry-Jones (1972), p. 84.

125. Finnane (1981), p. 21; Cox (2012), p. 2.

126. Hampstead Proceedings, 1825-1831 (Highfield Hospital Group, Records, 21 Aug. 1826).

127. Ibid., O'Hare (1998), p. 5. In 2014, under the name of Highfield Hospital Group, the establishment continued to be overseen by a sixth generation of the Eustace family. See Eustace Family Tree (Highfield Hospital Group, Records).

128. Parry-Jones (1972), p. 85.

129. O’Hare (1998), p. 1. 
130. 5 \& 6 Vic., c. 123, s. 18.

131. Parry-Jones (1972), p. 284.

132. Ibid., pp. 106-107.

133. See Mauger (2012).

134. Hampstead Proceedings, 1825-1831 (Highfield Hospital Group, Records, 1 Nov. 1825).

135. Report into the State of Lunatic Asylums, Part II, p. 159.

136. Ibid., pp. 155, 159.

137. Ibid., p. 159.

138. Ibid., p. 154.

139. See Burnett (1969).

140. For example, Medical Directories, London and Provincial, Scotland, Ireland (London, 1862), p. 1075.

141. Report into the State of Lunatic Asylums, Part II, p. 154.

142. Patient Accounts (Highfield Hospital Group, Records).

143. Forty-Third Report of the Inspectors of Lunatics (Ireland), H.C. 1894, p. 168.

144. Medical Directories, London and Provincial, Scotland, Ireland (London, 1877), p. 1616; (London, 1887), p. 1616; (London, 1889), p. 1718.

145. Medical Directories, London and Provincial, Scotland, Ireland (1876), p. 1290.

146. Parry-Jones (1972), p. 125.

147. MacKenzie (1992), pp. 128, 135.

148. Ibid., pp. 167, 172.

149. Thirty-Fourth Report on the District, Criminal, and Private Lunatic Asylums in Ireland [C 4539], H.C. 1884-1885, xxxvi, 635, p. 15.

150. Thirty-Sixth Report on the District, Criminal, and Private Lunatic Asylums in Ireland [5121], H.C. 1887, xxxix, 591, p. 20.

151. Report into the State of Lunatic Asylums, Part II, p. 154.

152. Ibid., p. 159.

153. Ibid.

154. Parry-Jones (1972), p. 86.

155. Report into the State of Lunatic Asylums, Part II, p. 159.

156. 'Insolvent Debtors,' The Nation, June 2, 1855.

157. Malcolm (1989), p. 179.

158. Ibid.

159. Prospectus of St John of God Hospital, 1884 (SJOGH, Records).

160. Parry-Jones (1972), pp. 168, 201-202.

161. Ibid.

162. Ibid., p. 207, Digby (1985), p. 218.

163. Digby (1985), p. 219; Parry-Jones (1972), p. 208. 
164. Digby (1985), p. 218.

165. Malcolm (1999), p. 180.

166. In Malcolm's study, over one-quarter stayed for five years or more, although Cox has found a smaller number of long-stay patients at the Carlow asylum in this period. Malcolm (1999, p. 180), Cox (2012), p. 141 .

167. Parry-Jones (1972), p. 212.

168. Ibid. Digby has found similar in her comparison of death rates at the York Retreat and neighbouring York asylum. Digby (1985), p. 225.

169. Malcolm (1999), p. 181.

170. Finnane (1981), p. 188.

171. Parry-Jones (1972, pp. 211-212), Digby (1985), p. 231.

172. MacKenzie (1992), p. 121.

173. Digby (1985), p. 231.

174. Malcolm (1999), pp. 180-181.

175. Cox (2012), p. 153.

176. Ibid.

177. Ibid.

178. Parry-Jones (1972), p. 208.

179. Walsh (2001), p. 145.

180. Case Book (FHL, Bloomfield Records, pp. 73, 75 ).

181. Catherine Cox and Hilary Marland have identified a significant preponderance of Irish-born patients in a number of pauper asylums in the north-west of England. See Cox and Marland (2015), pp. 263-287.

182. Case Book (FHL, Bloomfield Records, pp. 40, 47).

183. Cox (2012), p. 23.

184. Ibid.

185. Parry-Jones (1972), p. 86.

\section{REFERENCES}

Burnett, John. A History of the Cost of Living. Harmondsworth, 1969.

Busfield, Joan. Managing Madness: Changing Ideas and Practices. London, 1986.

Cox, Catherine. 'Access and Engagement: The Medical Dispensary System in Post-Famine Ireland.' In Cultures of Care in Irish Medical History, 17501970, edited by Catherine Cox and Maria Luddy, 57-78. Basingstoke, 2010.

Cox, Catherine. Negotiating Insanity in the Southeast of Ireland 1830-1900. Manchester: Manchester University Press, 2012.

Cox, Catherine and Hilary Marland. "A Burden on the County": Madness, Institutions of Confinement and the Irish Patient in Victorian Lancashire'. Social History of Medicine 28, no. 2 (2015): 263-287. 
Digby, Anne. Madness, Morality and Medicine: A Study of the York Retreat, 17961914. Cambridge: Cambridge University Press, 1985.

Finnane, Mark. Insanity and the Insane in Post-Famine Ireland. London: Croom Helm, 1981.

Finnane, Mark. 'Law and the Social Uses of the Asylum in Nineteenth-Century Ireland.' In Asylum in the Community, edited by John Carrier and Dylan Tomlinson, 88-107. London, 1996.

Luddy, Maria. Women and Philanthropy in Nineteenth-Century Ireland. Cambridge: Cambridge University Press, 1995.

MacKenzie, Charlotte. Psychiatry for the Rich: A History of the Private Madhouse at Ticehurst in Sussex, 1792-1917. London, Routledge 1992.

Malcolm, Elizabeth. Swift's Hospital: A History of St Patrick's Hospital, Dublin, 1746-1989. Dublin: Gill and Macmillan, 1989.

Malcolm, Elizabeth. 'The House of Strident Shadows: The Asylum, the Family and Emigration in Post-Famine Rural Ireland.' In Medicine, Disease and the State in Ireland 1650-1940, edited by Elizabeth Malcolm and Greta Jones, 177-195, Cork: Cork University Press, 1999.

Marland, Hilary. Dangerous Motherhood: Insanity and Childbirth in Victorian Britain. Basingstoke: Palgrave Macmillan, 2004.

Mauger, Alice. "“Confinement of the Higher Orders": The Social Role of Private Lunatic Asylums in Ireland, c. 1820-1860.' Journal of the History of Medicine and Allied Sciences 67, no. 2 (2012): 281-317.

Melling, Joseph and Bill Forsythe. The Politics of Madness: The State, Insanity and Society in England, 1845-14. London and New York: Routledge, 2006.

O'Hare, Pauline. In the Care of Friends. Dublin: Highfield Healthcare, 1998.

Parry-Jones, William Ll. The Trade in Lunacy: A Study of Private Madhouses in England in the Eighteenth and Nineteenth Centuries. London: Routledge \& Kegan Paul, 1972.

Preston, Margaret H. Charitable Words: Women, Philanthropy and the Language of Charity in Nineteenth-Century Dublin. Westport, Conn.: Praeger, 2004.

Smith, Leonard D. Cure, Comfort and Safe Custody: Public Lunatic Asylums in Early Nineteenth-Century England. London and New York, 1999a.

Smith, Leonard D. 'The County Asylum in the Mixed Economy of Care, 18081845.' In Insanity, Institutions and Society, 1800-1914, edited by Joseph Melling and Bill Forsythe, 33-47. London and New York: Routledge, 1999b.

Suzuki, Akihito. Madness at Home: The Psychiatrist, the Patient and the Family in England, 1820-1860. Berkeley and Los Angeles, 2006.

Walsh, Oonagh. 'Lunatic and Criminal Alliances in Nineteenth-Century Ireland.' In Outside the Walls of the Asylum: The History of Care in the Community 1750-2000, edited by Peter Bartlett and David Wright, 132-152. London: Athlone Press, 2001. 
Walsh, Oonagh. Anglican Women in Dublin: Philanthropy, Politics and Education in the Early Twentieth Century. Dublin, 2005.

Walton, John. 'Lunacy in the Industrial Revolution: A Study of Asylum Admission in Lancashire, 1848-50.' In Journal of Social History 13, no. 1 (1979-1980): 1-22.

Wright, David. 'Family Strategies and the Institutional Confinement of 'Idiot' Children in Victorian England.' Journal of Family History, 23, no. 2 (April, 1998): 190-208.

Open Access This chapter is licensed under the terms of the Creative Commons Attribution 4.0 International License (http://creativecommons.org/licenses/ by $/ 4.0 /$ ), which permits use, sharing, adaptation, distribution and reproduction in any medium or format, as long as you give appropriate credit to the original author(s) and the source, provide a link to the Creative Commons license and indicate if changes were made.

The images or other third party material in this chapter are included in the chapter's Creative Commons license, unless indicated otherwise in a credit line to the material. If material is not included in the chapter's Creative Commons license and your intended use is not permitted by statutory regulation or exceeds the permitted use, you will need to obtain permission directly from the copyright holder.

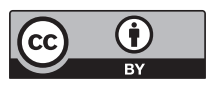

